\title{
КЛІНІЧНИЙ ВИПАДОК: ЗАГЛОТКОВИЙ АБСЦЕС У ДИТИНИ
}

\author{
Тернопільський національний медичний університет імені І.Я. Горбачевського, \\ КНП «Тернопільська обласна дитяча клінічна лікарня» ТОР
}

\begin{abstract}
Заглотковий абсцес у дітей є небезпечним захворюванням, яке виникає внаслідок гнійного розплавлення ліморатичних вузлів і пухкої клітковини позаду глоткового простору. Він найчастіше трапляється у дітей віком до 4 років і є наслідком ГРВІ, гострого ринофарингіту, отиту, риносинуситу, тонзиліту, аденоїдиту або травми задньої стінки глотки. У випадку наявності гною першочерговим є розтин абсцесу.

У статті наведено аналіз типового клінічного випадку заглоткового абсцесу рідкісної локалізації (носоглотка) у дитини 7 років, яка перебувала на стаціонарному лікуванні в отоларингологічному відділенні дитячої лікарні. Проведене лікування сприяло повному видужанню дитини, про що засвідчили віддалені результати спостереження.
\end{abstract}

Вчасна діагностика та лікування $є$ запорукою повного видужання пацієнта. В протилежному випадку можливе виникнення ряду небезпечних ускладнень.

Ключові слова: заглотковий абсцес, діагностика, лікування.

Заглотковий абсцес у дітей є небезпечним захворюванням, яке виникає внаслідок гнійного розплавлення лімсратичних вузлів і пухкої клітковини позаду глоткового простору. Частіше спостерігається в дошкільному віці. Може розташовуватись у різних поверхах глотки (носоглотці, ротоглотці чи гортаноглотці).

Це захворювання розвивається переважно на фоні ГРВІ, гострого риносрарингіту, отиту, риносинуситу, тонзиліту, аденоїдиту або травми задньої стінки глотки. Етіологічним чинником заглоткового абсцесу $€$ аеробна (Streptococcus pyogenes, Staphylococcus aureus, Haemophilus influenzae та ін.) й анаеробна (Fusobacterium, Peptostreptococcus, Prevotella, Bacteroides) мікрофрлора. Збудник через лімфатичні судини проникає в заглоткові лімфовузли і спричиняє їхнє гнійне запалення [1, 2].

Пацієнтка Л., 7 років, перебувала на стаціонарному лікуванні в ЛОР-відділенні дитячої лікарні. Загальний стан відповідав середній тяжкості. При ушпиталенні скаржилася на постійний біль у горлі, утруднені ковтання та розгинання голови. Температура тіла $39{ }^{\circ} \mathrm{C}$. Скарги вперше з'явилися за 7 діб до госпіталізації (лікувалася лише за допомогою нурофрена, ефект від якого з кожним днем зменшувався). При орофрарингоскопії рот відкривала вільно, слизова оболонка губ, щік, ясен, твердого та м'якого піднебіння була рожева, волога. Піднебінні дужки контурувалися, були рожевого кольору, піднебінні мигдалики виходили за передні піднебінні дужки, лакуни не мали патологічного вмісту, поверхня залишалася гладкою. Задня стінка глотки була волога, блідо-рожевого кольору, без ознак запалення. Глотковий рефлекс зберігався. Носоглотка: склепіння вільне, слизова оболонка рожева, волога, хоани вільні, задні кінці верхніх, середніх і нижніх носових раковин не збільшені. Вічка слухових труб добре дифреренційовані, вільні. Спостерігається легка асиметрія глотки по задній стінці справа. Гортаноглотка: язиковий мигдалик не збільшений, валекули вільні, задня та бокові стінки глотки рожеві, вологі, грушоподібні синуси при фронації добре розкриваються, вільні, їх слизова оболонка рожева, волога. Дані отоскопії та передньої риноскопії в межах вікової норми. За даними МРТ, картина великого правобічного заглоткового інфрільтрату з фрормуванням абсцесу. Потовщення та інфрільтрація заглоткових м яких тканин з наявністю лінійної рідинної колекції (абсцесу). Субстенозування просвіту глотки. Виражена двобічна шийна лімфаденопатія (лімфаденіт) (мал. 1).

Загальний аналіз крові вказував на лейкоцитоз і зсув формули вліво (гем. 90 г/л; ер. 3,0 Т/л; КП 0,9; лейк. 11,0 Г/л; ШOE 40 мм/год; п. 1, с. 82, е. 0, б. 0, л. 14, м. 3 \%).

У перший день стаціонарного лікування на підставі наведених даних діагностовано заглотковий абсцес справа. Проведено хірургічне розкриття його у місці найбільшого випинання, відступивши 1 см від середньої лінії шиї в ділянці носоглотки. Отримано незначну кількість гнійного вмісту, проведено його аспірацію гнучким катетером. Отриманий матеріал відіслано на бактеріологічне дослідження.

Пацієнтка відзначила значне полегшення загального стану на другий день після хірургічного втручання, температура тіла $37,2{ }^{\circ} \mathrm{C}$. 3 дня ушпиталення отримувала цесттриаксон по 1,0 2 рази на добу вутрішньовенно та ібупрофен по 1 табл. (200 мг) 3 рази на добу. На третій 


\section{КОРОТКІ ПОВІДОМЛЕННЯ}

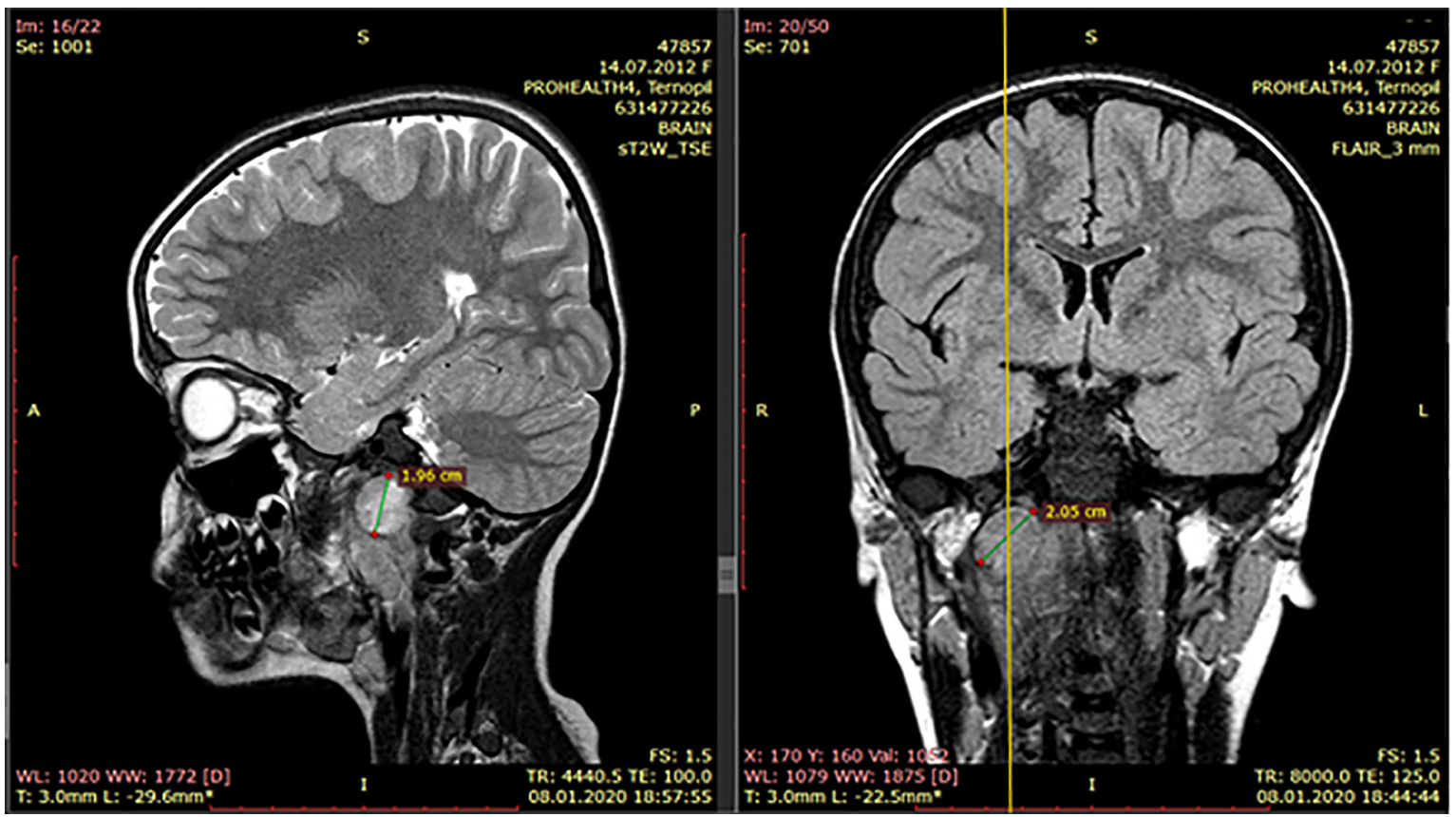

Мал. 1. Хвора Л., 7 років. Магнітно-резонансна томограма голови в сагітальній і коронарній проекціях. Визначаються потовщення та інфільтрація м `яких тканин справа, парацентрально й заглотково, на фроні яких чітко контурується рідинна колекція розмірами 31×20×20 мм, неоднорідний гіпер/ізоінтенсивний МР-сигнал на Т2.

день лікування загальний стан дитини погіршився: збільшився біль у глотці, утруднилися ковтання та розгинання голови. Тому проведено ревізію післяопераційної рани, отримали велику кількість гною. До попереднього лікування додано: фрізіологічний розчин хлориду натрію 200,0 + дексаметазон 4 мг внутрішньовенно, розчин глюкози $5 \%$ 200,0 + аскорбінова кислота 2,0 внутрішньовенно, розчин Рингера 200,0 внутрішньовенно, метрагіл 33 мл 3 рази на добу внутрішньовенно. Результат бактеріологічного дослідження - S. viridans, чутливий до амікацину, цефотаксиму, чефоперазону.

На 8-й день захворювання загальний стан задовільний, клінічних ознак заглоткового абсцесу немає. Загаль-

\section{Література}

1. https://shdm.school/clinical-studies/clinical-lectures/2104zaglotkovij-abstces.

2. Тишко Ф.О. Заглотковий абсцес / Ф.О. Тишко, О.В. Павлова // Здоров'я України. - 2011. - вересень. - С. 60-62. ний аналіз крові: гем. 94 г/л; ер. 3,13 Т/л; лейк. 9,24 Г/л; ШOE 30 мм/год; п. 2, с. 70, е. 2, б. 0, л. 22, м. 4 \%. Виписана під амбулаторне спостереження, яке тривало 3 міс. Констатовано стійке видужання.

Таким чином, завдяки вчасній діагностиці та наданій допомозі вдалося досягти повного видужання пацієнтки. Але треба пам'ятати, що неправильний діагноз і несвоєчасна допомога в такій клінічній ситуації призводить до ряду небезпечних ускладнень - розвитку гострого стенозу гортані різного ступеня, набряку гортані, розповсюдження запалення у міжфасціальні простори шиї та середостіння, пневмонії, сепсису та ін.

\section{References}

1. https://shdm.school/clinical-studies/clinical-lectures/2104zaglotkovij-abstces.

2. Tyshko, F. O., \& Pavlova, O. V. (2011). Retropharyngeal abscess. Health of Ukraine, 60-62 [in Ukrainian]. 


\section{КОРОТКІ ПОВІДОМЛЕННЯ}

\section{CLINICAL CASE: RETROPHARYNGEAL ABSCESS IN A CHILD}

I.M. Andreichyn, V.I. Omeliash

I. Horbachevsky Ternopil National Medical University,

Ternopil Regional Children's Clinical Hospital

SUMMARY. Retropharyngeal abscess in children is a dangerous disease that results from purulent melting of lymph nodes and loose tissue behind the pharyngeal space. The pharyngeal abscess is most common in children under 4 years of age and is a result of ARVI, acute rhinopharyngitis, otitis, rhinosinusitis, sore throats, adenoiditis or trauma to the posterior pharyngeal wall. In the case of pus, the abscess section is of paramount importance.

In this article, an analysis of a typical clinical case of a pharyngeal abscess of a liquid localization (nasopharynx) in a 7 year old child, who was hospitalized in the otolaryngology department of a pediatric hospital. The conducted treatment contributed to the full recovery of the child as evidenced by the long-term observation results.

Timely diagnosis and treatment are the key to complete recovery of the patient. Otherwise, a number of dangerous complications may occur.

Key words: pharyngeal abscess; diagnosis; treatment.

\section{Відомості про авторів:}

Андрейчин Юрій Михайлович - д. мед. н., профресор кафредри оториноларингології, офртальмології та нейрохірургії Тернопільського національного медичного університету імені І.Я. Горбачевського; e-mail: yandrachyn@tdmu. edu.ua;

ORCID iD: https://orcid.org/0000-0002-7789-4466

Омеляш Володимир Іванович - лОР-лікар КНП «Тернопільська обласна дитяча клінічна лікарня» TOP; e-mail: wowaom13@gmail.com

Information about the authors:

Andreichyn lu.M. - MD, Professor of the Department of Otolaryngology, Ophthalmology and Neurosurgery of I. Horbachevsky Ternopil National Medical University; e-mail: yandrachyn@tdmu.edu.ua

ORCID ID: https://orcid.org/0000-0002-7789-4466

Omeliash V.I. - Otolaryngologist of the Municipal Non-profit Enterprise «Ternopil Regional Children's Clinical Hospital» of Ternopil Regional Council; e-mail: wowaom13@gmail.com

Конфолікт інтересів: немає.

Authors have no conflict of interest to declare.

Отримано 16.02.2020 р. 